\title{
Size and Value Premium in Karachi Stock Exchange
}

\author{
Nawazish Mirza* and Saima Shahid**
}

\begin{abstract}
This study evaluates the ability of the Fama and French Three Factor model to explain a cross section of stock returns in the Karachi Stock Exchange (KSE). Following Fama and French factor approach, we sorted six portfolios by size and book to market. The sorted portfolios were constituted to represent stocks from each and every sector of KSE. Using Daily returns from January 2003 to December 2007, the excess returns for each portfolio were regressed on market, size and value factors. Our findings, in general, supported the notion of the three factor model. The three factor model was able to explain the variations in returns for most of the portfolios and the results remain robust when the sample was reduced to control for the size effect. Our findings are consistent with most of the studies that suggested the validity of the three factor model in emerging markets. These results warrant for the inclusion of size and value factors for valuation, capital budgeting and project appraisals, thus, having substantial implications for fund managers, analysts and investors.
\end{abstract}

JEL Classification: G11, G12, G14.

Keywords: Size Premium, Value Premium, Market Premium, Three-Factor Mode1.

\section{Introduction}

The Fama and French (FF) three-factor model has emerged as an alternative explanation for the ongoing debate on asset pricing. FF start with the observation that two classes of stocks have performed better than the market as a whole. These include stocks with small market capitalization and stocks with high book-to-price ratios (market value). The book-tomarket ratio compares the book value of a stock's equity with that of its market value. High book-to-market ratio stocks are termed value stocks while low book-to-market stocks are called growth stocks. Since these stocks yielded a higher return than the market, FF observed that such a

\footnotetext{
* PHD Candidate at Financial Markets Group, Paris, Dauphine.

${ }^{* *}$ Research Associate at Center for Policy Studies, Lahore School of Economics.
} 
phenomenon was explained by the existence of size as well as value premium in addition to the market risk premium as posited by the traditional Capital Asset Pricing Model (CAPM).

To account for these two premia, FF constructed two more risk factors outside of market risk. They used $S M B$ (small minus big) to address size risk and $H M L$ (high minus low) for value risk. The size factor measures the additional returns investors receive for participating in stocks with comparatively small capitalization. The positive $S M B$ factor represents more returns for small cap stocks vis-à-vis big stocks and vice versa. The value factor captures what premium investors will get while investing in stocks with a high book-to-market ratio. A positive $H M L$ signifies more returns for value stocks than growth stocks.

The three-factor model can be expressed as follows:

$$
E\left[R_{i t}\right]-R_{f t}=\beta_{i_{1}}\left(E\left[R_{m t}\right]-R_{f t}\right)+\beta_{i_{2}}\left[S M B_{t}\right]+\beta_{i_{3}}\left[H M L_{t}\right] \quad 1
$$

Where $E\left[R_{i t}\right]$ represents expected return on stock $i, E\left[R_{m t}\right]-R_{f t}$ represents market premium, $S M B_{t}$ is the size premium, and $H M L_{t}$ represents value premium. The coefficients represent the risk sensitivities for market risk $\left(\beta_{i, 1}\right)$ followed by size $\left(\beta_{i, 2}\right)$ and value $\left(\beta_{i, 3}\right)$. The market risk coefficient is akin to Sharpe's CAPM but different in the sense that the three-factor model's explanatory function will be shared by two other risk factors.

Markets outside North America and Western Europe have grown rapidly in the last two decades. A significant change in financial markets is the evolution of emerging markets where the potential for investment in terms of risk and return is reasonably high. The International Finance Corporation (IFC) rates approximately 30 countries as emerging markets, which are characterized by distinct market dynamics and investment behavior. These economies have smaller financial markets in proportion to their economies size vis-à-vis developed markets. Other important aspects of emerging markets are the level of activity and their openness to foreign investors. In the presence of thin trading, informational inefficiency, panics, bubbles, and lack of transparency, overall investor activity remains range-bound to certain stocks ( $\mathrm{Li}$ and Richard 2004). These differentiating factors warrant an examination of the behavior of asset pricing in emerging markets. With monetary integration and globalization, investors tend to diversify their portfolios by participating in developed as well as emerging international markets. Therefore, it is vital to analyze the applicability of asset pricing models in an emerging scenario to support investment decisions. 
Pakistan has been classified as an emerging market. Unfortunately, the Pakistani literature on asset pricing is very rare in general and almost nonexistent as far as size and value premium are concerned. There are three stock exchanges ${ }^{1}$ in Pakistan with the Karachi Stock Exchange (KSE) being the most liquid and the biggest in terms of market capitalization and trading volume and been awarded the title of "best performing emerging stock market of the world" in 2002 by Business Week.

The FF three-factor model has emerged as an alternative explanation for the ongoing debate on asset pricing ${ }^{2}$. The discrepancies in CAPM have contributed to the success of alternative explanations. Fama and French (1998) advocate a global version of their model. They studied 13 world markets during 1975-1995 and showed that value stocks tend to yield higher returns than growth stocks. They also sorted the portfolios on bookto-markets ratio and found that, in 12 of 13 countries, value stocks outperformed growth stocks. Similar results were observed for emerging markets. They noted that an international CAPM did not explain value premiums in international markets.

Although the FF model is quite simple, there is considerable empirical controversy over the interpretation of its risk factors. Some researchers have proposed that the existence of the book-to-market premium is not due to investors' compensation for risk bearing as much as investors' overreactions (Lakonishok, Shleifer, and Vishny 1994, Haugen (1995)]. They suggest that investors overreact to corporate news and exaggerate their estimates about future growth. Consequently, value stocks tend to be under-priced while growth stocks tend to be over-priced. Another group of critics relates the success of the FF model to empirical gimmicks (Ferson, Sarkissian, and Simin 1999). They suggest that the explanatory power of the three-factor model is due to econometric irregularities. This could be due to inherent biases or data mining that exaggerates results for the three-factor model. Berk (1995) suggests that the way in which portfolios for high book-to-market and size ratios are constructed implies that they are expected to yield high returns, regardless of any economic interpretation.

\footnotetext{
${ }^{1}$ These include Karachi Stock Exchange (KSE), Lahore Stock Exchange (LSE) and Islamabad Stock Exchange (ISE).

${ }_{2}$ The significant literature on asset pricing models and their subsequent extensions include propositions by Tobin's (1958) separation theorem, Sharpe (1964), Linter (1965), Mossin (1966) capital asset pricing model (CAPM), Black's (1972) Zero Beta CAPM, Merton's (1973) Intertemporal CAPM, Breeden's (1979) consumption based CAPM and Ross's (1976) Arbitrage Pricing Theory.
} 
The aim of this article is to study the power of the FF three-factor model to explain returns on KSE traded stocks. The outcome of this research could provide an insight into the model's capacity to explain the puzzling risk-return relationship in an emerging market.

The rest of the paper is organized as follows. Section II summarizes some of the existing literature on size and value premiums. Section III discusses the data and methodology used. Empirical results are presented in Section IV, and Section V concludes the article.

\section{Literature Review}

Fama and French (1992) examine a cross section of stock returns and present the additional factors of size and value premium to clarify the return anomalies that CAPM was unable to explain. They use nonfinancial firms' data from NYSE, AMEX, and NASDAQ for the period 1962-1989. Stocks are sorted by size (measured by the market value of equity) for all three markets, and ten size-based portfolios constructed. The model is tested using the Fama-MacBeth regression approach. The results support the notion that size helps explain the cross section of returns; while beta alone is not sufficient to explain the variations. Similar results are obtained for the book-to-market (value premium) ratio. Fama and French note that, although the book-to-market ratio has a stronger impact than size, it cannot replace the latter in explaining average returns; when both are combined in the model, it yields even better results.

They conclude (i) that, if asset pricing is rational, the additional risk factors of size and book-to-market ratio seem to describe average returns, and (ii) that the probability that such results were due to chance is remote. They add that economic fundamentals suggest that high book-to-market ratio firms are likely to remain less profitable vis-à-vis low book-to-market firms. Moreover, during the sample period, small firms generated fewer earnings than bigger firms. Thus, it is likely that these variables are considered by investors while pricing an asset. On a concluding note, Fama and French argue that according to a rational pricing decision, investors are likely to factor in size and value premium. They do, however, admit that if stock prices emerge from irrational investment behavior, there is a smaller chance that their results will persist.

Fama and French (1993) extend their 1992 research by applying a time series regression approach. The analysis was extended to both stocks and bonds. The monthly average returns on stocks and bonds were regressed on five other factors: (i) excess returns on market portfolio, (ii) 
portfolios sorted by size, (iii) portfolios sorted by book-to-market ratio, (iv) term premium, and ( $\mathrm{v}$ ) default premium. They found that the first three factors were significant for stocks while the last two were significant in explaining returns on bonds. They confirmed the existence of size and value premia in US returns and commented that a three-factor model provided a better explanation for the risk return puzzle.

Fama and French (1995) try to provide an economic rationale for their three-factor model by relating risk factors to earning shocks. They study the characteristics of value as well as growth firms. Their analysis is that firms with a high book-to-market ratio tend to in consistent distress, while firms with a low book-to-market ratio show sustained profitability. This leads to the conclusion that returns on high book-to-market stocks compensate for holding less profitable and riskier stocks. The results demonstrate that the sensitivities of HML and SMB are a proxy for relative distress. Firms with low earnings had a high book-to-market ratio and a positive slope for HML, while firms with high earnings had a low book-tomarket ratio and a negative HML slope.

Claessens et al (1995) examine a cross section of asset returns in emerging markets. They use data from the International Finance Corporation (IFC) for 18 developing countries for the period 1986-1993, and analyzed the impact of risk factors, besides betas, and their impact on asset returns. They conclude that, in addition to beta, two factors, i.e., size and trading volume have the highest explanatory power in most countries. Dividend yield and earning-to-price ratio were also significant but in fewer countries. Lastly, they propose that exchange rate risk is an important determinant of asset returns.

Daniel and Titman (1997) use a factor analysis approach to study the impact of loadings on stock returns from 1973-1993. They investigate the rationale behind different returns on portfolios that have similar characteristics with varying factor loadings. After controlling for the size and book-to-market ratio, they find that expected returns are not a function of loadings on the Fama and French risk factors. They posit that it is the covariance between high book-to-market ratio stocks that leads to similar properties rather than a common risk factor.

Halliwel et al (1999) replicate the Fama and French (1993) study using Australian data. Their results suggest some premia on small sized and high book-to-market ratio stocks. Despite observing some premia on the SMB and HML factors, there are some inconsistencies with respect to the FF three-factor model. First, the explanatory power of the three-factor 
mode1 is not as strong as was observed in the case of US markets. Second, Fama and French (1993) report that there is a tendency for size sensitivity to fall when moving from lower to higher book-to-market portfolios. However, Halliwel et al (1999) do not find any evidence for the decrease in size sensitivity, given a transition from low to high book-to-market ratio stocks. Third, Fama and French (1993) report a significant improvement in the adjusted $R^{2}$ when they move from a single factor to three factors, while Halliwel et al (1999) observe only a marginal improvement in $R^{2}$.

Davis et al (2000) make an extensive study of the characteristics, covariances and average returns of a sample from 1929 to 1997. They decompose the sample into two periods. The first observation period is from July 1929 to June 1963, and the second from July 1963 to June 1997. The value premium, measured by the HML factor for the first half was $0.5 \%$ per month and was statistically significant $(\mathrm{t}=2.80)$. This is similar to the value premium observed by other authors for the second period, valuing $0.43 \%$ per month with a higher significance level $(\mathrm{t}=$ 3.38). However, the observed size premium was lower than the value premium. Represented by the SMB factor, the size premium was $0.20 \%$ for the whole sample period. They conclude that the value premium in average stock returns is robust. Their sample period is longer than that of Daniel and Titman (1997), and their results contradict those of the latter: Davis et al (1997) find a relationship between returns and factor loading, and suggest that Daniel and Titman (1997) results were subject to a low power of tests and a comparatively shorter time span.

Aleati et al (2000) investigate the relationship between risk factors and returns for Italian stocks. They use factor analyses and time series regressions to identify the economic variables in Italian stock markets. They use the stocks listed on the Italian Stock Exchange from 1981-1993. Unlike most researchers, they use individual stock returns rather than portfolio returns due to the small number of listed firms in Italy. Aleati et al find out that changes in market index, oil prices, default premium, interest rates, and $\mathrm{SMB}$ and $\mathrm{HML}$ are viable factors for determining asset returns in Italy. The SMB and HML factors are priced in the market even when other macroeconomic variables are added.

Connor and Sehgal (2001) compare the three-factor model with CAPM to determine which model better explains the cross section of portfolio returns in the Indian stock market. The sample companies for their study were drawn from CRISIL 500 (similar to the S\&P index in the US). The companies were sorted by book-to-market ratio, taking above-median stocks as high and below-median stocks as low. Market capitalization was 
similarly sorted with the upper $30 \%$ as $b i g$, the middle $40 \%$ as medium, and the lower $30 \%$ as small. Further, six portfolios were formed on the intersection of size and book-to-market sorting. Connor and Sehgal (2001) analyze the comparative level of intercepts by applying the adjusted Wald Statistic. In CAPM, three out of six portfolios showed a significant intercept, while in the FF three-factor model, intercepts for all six portfolios were insignificant. Based on the evidence provided by the intercepts of time series regression for both models, the authors conclude that the FF three-factor model is a better fit for the Indian stock market.

Drew and Veeraraghavan (2002) study the existence of size and value premiums in emerging markets. Using data for the Malaysian market from December 1991 to December 1999, they form six portfolios at the intersection of two size and three book-to-market portfolios. Their findings imply the existence of size and value premiums that are not documented by the CAPM. They observe that the SMB and HML portfolios generate average returns of $17.7 \%$ and $17.6 \%$, with a standard deviation of $5.3 \%$ and $6.1 \%$, respectively; while the market or index returns for the period was substantially lower at $1.92 \%$, demonstrating a much higher risk premium for the size and value factors. They reject the possibility that these results could be due to a survivorship bias or data mining. Further, they reject the possibility of seasonality in returns and comment that the explanatory variables are strong enough throughout the period to reject the presence of the turn-of-the-year effect. Thus, the evidence supports the notions of value and size premium in international markets.

Beltratti and Di Tria (2002) assess the relevance of multifactor asset pricing models for Italian stocks from 1991 to 2000. The purpose of their research is to analyze the extent to which financial variables can be used as proxies for macroeconomic risk and their relation with the business risk. They compare four asset pricing models, including the simple CAPM, the FF three-factor model, a multifactor model including sectors, and a multifactor model including changes in short-term interest rates. Furthermore, they also study the impact of sample design on the construction of HML and SMB factors.

The results demonstrate that the FF three-factor model, among others, best explains the cross section of returns in Italian markets. The explanatory power of the model is dependent on the approach of the tests. The time series estimates resulted in constants that were significant, while in cross section regressions, none of the coefficients was significant although theory suggests that average risk premiums should be significantly positive. They attribute these discrepancies to the instability in Italian markets that 
has generated unexpected returns for the investors; and commented that the time series approach is best used for the Italian market; time series analysis reveals the FF three-factor model to be most appropriate. However, they point out that the result could not establish a robust relationship between $\mathrm{SMB}, \mathrm{HML}$, and certain important macroeconomic variables. They propose the existence of other local factors that might better explain the variability in returns. Lastly, they raise the issue of strong non-normality in returns for the factor portfolios.

Drew and Veeraraghavan (2003) compare the explanatory power of a single-index model with that of the FF three-factor model. The countries examined are Hong Kong, Korea, Malaysia, and Philippines. They conclude that there were size and value premiums in these markets and that the three-factor model better explained the variations in return for these markets. They comment that the premiums are compensation for risk that is not accounted for by CAPM.

\section{Research Methodology}

As mentioned earlier, the dynamics of emerging markets are different from developed ones. KSE was declared an open market in 1991 although the pace of market activity remained stagnant till 2002. Starting from 2003, Pakistani markets have seen a new bull rally that continued until March 2008 with some corrections and a few panics. In general, however, investor sentiment is positive and it is believed that the market hype is backed by strong fundamentals. The pre-2003 era was dominated by low activity, fewer investors, and high transaction costs.

The sample 5-year period thus chosen for this study was from 1 January 2003 to 31 December 2007. Another reason that validates this time period selection is the events of 11 September 2001. The post-9/11 world has presented a completely different investment scenario. Attributes and investment behavior are more cautious and risk averse. Had the sample period included both pre- and post-9/11 data, the difference in investment characteristics could have created a potential bias in results, which is why it seemed prudent to include a 1-year lag and start with data for January 2003.

\section{III.I. Model Specification}

Fama and French contend for a multifactor asset-pricing model: their three-factor model is an extension of a single-factor CAPM. Besides

the traditional beta, it includes two additional factors to account for size 
and value premiums. Mathematically, we can represent the three-factor mode1 as

$E\left[R_{i t}\right]=R_{f t}+\left(E\left[R_{m t}\right]-R_{f}\right) \beta_{i, 1}+\left(S M B_{t}\right) \beta_{i, 2}+\left(H M L_{t}\right) \beta_{i, 3}$

with $t=1,2,3, \ldots, T$

Where $E\left[R_{i t}\right]$ represents expected return on stock $i, E\left[R_{m t}\right]-R_{f t}$ represents market premium, $S M B_{t}$ is the size premium and $H M L_{t}$ represents the value premium. The coefficients are the risk sensitivities of returns for market risk $\left(\beta_{\mathrm{i}, 1}\right)$ followed by size $\left(\beta_{\mathrm{i}, 2}\right)$ and value $\left(\beta_{\mathrm{i}, 3}\right)$.

To test the FF three-factor model, we follow the traditional multivariate regression framework and transform the above equation into a simple time series model represented as follows:

$$
E R_{i t}=\alpha_{i}+R P_{t} \beta_{i, 1}+\left(S M B_{t}\right) \beta_{i, 2}+\left(H M L_{t}\right) \beta_{i, e}+e_{i t}
$$

Where $E R_{i t}=E\left[R_{i t}\right]-R_{f t}$ is the excess return on stock $i$, $R P_{t}=E\left[R_{m t}\right]-R_{f t}$ is the risk premium, $\alpha_{i}$ is the intercept of the regression equation representing a nonmarket return component, while $e_{i t}$ represents a random return component due to unexpected events related to a particular stock. We assume that $e_{t}$ has a multivariate normal distribution and is independently and identically distributed over time. If the model holds, $\alpha_{i}$ will prove nonsignificant.

The above model represents the three-factor model for an individual stock. By replacing security $i$ with a portfolio of stocks $\mathrm{P}$, the three-factor model can be expressed as follows:

$$
E R_{P t}=\alpha_{P}+R P_{t} \beta_{i, 1}+\left(S M B_{t}\right) \beta_{i, 2}+(H M L) \beta_{i, 3}+e_{i t}
$$

Where $E R_{P t}=R_{P t}-R_{f}$ and $R_{P t}=\sum_{i=1}^{N} w_{i} R_{i t}$ with $w$ representing the weight of stock in portfolio. 
Thus, the excess portfolio return can be reflected as $E R_{P t}=\sum_{i=1}^{N} w_{i} R_{i t}-R_{f}$, and the nonmarket return component will be $\alpha_{P}=\sum_{i=1}^{N} w_{i} \alpha_{i}$ which is the average of the individual alphas.

\section{III.II. Dependent and Independent Variables}

\section{III.II.I. Dependent Variable}

The dependent variable for the FF three-factor model is the excess portfolio return, represented by $E R_{P t}$. The excess return reflects the return over and above the risk-free rate required by the investor to justify risk taking. As already mentioned, the portfolio return is the weighted average of all stocks included in a portfolio.

\section{III.II.II. Independent Variables}

Independent variables include market risk premium, size factor, and value factor. Market risk premium, measured as the difference between the return on a market portfolio and risk-free rate, represents the excess return that an investor could earn if they invested in a market portfolio rather than a risk-free asset. The market risk premiums and excess return is the same in both the CAPM and three-factor model. However, the latter has two other variables. $S M B$ or size premium captures the additional return offered by small firms vis-à-vis big firms. Similarly, the $H M L$ or value premium captures the additional return offered by firms whose BV to MV ratio is lower.

The theoretical foundations of the $S M B$ and $H M L$ factors are intuitively appealing. Small companies are more sensitive to various risk factors because they are less diversified and have less financial flexibility than larger firms. Therefore, investors should require a risk premium while investing in small capitalization firms. The $H M L$ factor places a higher risk on value stocks than growth stocks. A high book-to-market ratio depicts a deviation in the book value of the firm from its market value, indicating that the market is not placing high value on stocks. This could be due to current distress or investors' expectations about future prospects, making such companies vulnerable to business risk as well as financial risk and, in turn, making it logical for investors to demand a premium on such stocks. 


\section{III.III. Sample Selection and Criteria Limitations}

As discussed earlier, this study tests the performance of the FF three-factor model when applied to the KSE for 5 years from 1 January 2003 to 31 December 2007. The sample consists of companies from all industrial and nonindustrial sectors listed on the KSE. Following is a list of criteria that was employed to select stocks from these individual sectors.

1. All selected stocks must be public limited companies listed on the KSE.

2. For selected companies, daily price data, book value and market value of equity, and market capitalization should be available.

3. The selected stocks must have survived the 5 -year period.

4. In order to avoid thinly traded stocks, only those stocks were included that had been traded for at least $90 \%$ of trading days during the sample period.

5. Fama and French do not include financial sector firms in their study. However, due to active participation of banking stocks in the KSE, we have not excluded the financial sector.

6. Once the sample was selected, it was sorted on the basis of market capitalization and compared across sectors. To eliminate extremely small firms and create some homogeneity with respect to size, the lower $5 \%$ was excluded. Based on this criterion, 81 companies were selected. Following the FF methodology, the portfolios were reformed in December of each year based on the book value of equity.

Table-1 summarizes the participation of each industrial sector in the selected sample. 
Table-1: Number of Selected Companies for Each Sector

\begin{tabular}{|c|c|c|c|}
\hline No & Sector & No. of Companies & \% in Sample \\
\hline 1 & Auto Assembler & 4 & $4.94 \%$ \\
\hline 2 & Automobile Parts & 1 & $1.23 \%$ \\
\hline 3 & Banks & 10 & $12.35 \%$ \\
\hline 4 & Cable and Electrical Goods & 1 & $1.23 \%$ \\
\hline 5 & Cement & 5 & $6.17 \%$ \\
\hline 6 & Chemicals & 2 & $2.47 \%$ \\
\hline 7 & Engineering & 2 & $2.47 \%$ \\
\hline 8 & Fertilizers & 3 & $3.70 \%$ \\
\hline 9 & Food and Personal Care & 5 & $6.17 \%$ \\
\hline 10 & Glass and Ceramics & 4 & $4.94 \%$ \\
\hline 11 & Insurance & 5 & $6.17 \%$ \\
\hline 12 & Jute & 1 & $1.23 \%$ \\
\hline 13 & Leasing & 3 & $3.70 \%$ \\
\hline 14 & Leather & 2 & $2.47 \%$ \\
\hline 15 & Oil and Gas Exploration & 2 & $2.47 \%$ \\
\hline 16 & Oil and Gas Marketing & 4 & $4.94 \%$ \\
\hline 17 & Paper and Board & 2 & $2.47 \%$ \\
\hline 18 & Pharmaceutical & 3 & $3.70 \%$ \\
\hline 19 & Power & 5 & $6.17 \%$ \\
\hline 20 & Refinery & 2 & $2.47 \%$ \\
\hline 21 & Sugar & 3 & $3.70 \%$ \\
\hline 22 & Technology & 2 & $2.47 \%$ \\
\hline 23 & Textiles & 5 & $6.17 \%$ \\
\hline 24 & Tobacco & 2 & $2.47 \%$ \\
\hline 25 & Transport & 2 & $2.47 \%$ \\
\hline \multirow[t]{2}{*}{26} & Vanaspati & 1 & $1.23 \%$ \\
\hline & Total & 81 & \\
\hline
\end{tabular}

The financial sector, including banks, insurance, and leasing stocks constitutes approximately $23 \%$ of the total selected sample. The higher proportion of financial firms in the sample is attributed to the activity of these stocks on the KSE with stocks like MCB, NBP, and Orix Leasing etc. 
leading in volume. As mentioned earlier, most studies have excluded the banking sector due to highly differentiated risk profiles. Another reason for excluding them is that, in most developed markets, banking stocks are subject to thin trading and are not dominant vis-à-vis other sectors. However, the dynamics in emerging markets in general and Pakistan in specific are such that the exclusion of the banking and financial sector is not justified. The dominance of the banking sector was deemed helpful in analyzing the robustness of the three-factor model.

The textiles sector has a moderate contribution of $6 \%$. Despite being the largest sector, the low participation of the textiles sector in our sample is due to the fact that most textile stocks are subject to thin trading, with some stocks reporting zero trade for the sample period. Other dominant sectors in the sample are automobile assemblers and power, some of which have highly liquid stocks.

\section{III.IV. Types and Sources of Data}

We use secondary data from the KSE for this study. As reported by Davis (1994), the frequency of returns estimate does not improve or deteriorate results. Daily returns were used to increase the number of observations. To estimate daily returns, we use daily closing stock prices. The observation of the true market portfolio within the framework of various asset-pricing models is not possible and for empirical studies synthetic market portfolios are used. Our aim was to mimic the market portfolio by using the KSE 100 index.

A risk-free asset is one that yields a certain return. In practice, no such assets exist and investors use government-issued securities as risk-free assets and their returns as risk-free rates. However, even if these securities are default risk-free, they are not entirely risk-free and, at the least, carry inflation risk. For this analysis, we use the six months' Pakistan treasury bill yield as a risk-free proxy.

\section{III.IV. Estimation of Variables}

\section{III.IV.I. Daily Portfolio and Market Returns}

Portfolio returns are the weighted average returns on individual stocks. These returns are estimated as follows ${ }^{3}$ :

\footnotetext{
${ }^{3}$ The prices are adjusted for dividends and therefore returns incorporates dividend factor.
} 
$R_{P t}=\sum_{i=1}^{N} w_{i} R_{i t}$, and $R_{i t}=L N\left[\frac{P_{t}}{P_{t-1}}\right]$, where $\mathrm{P}_{\mathrm{t}}$ and $\mathrm{P}_{\mathrm{t}-1}$ are closing prices on day $t$ and $t-1$. These individual returns are then weighted according to their contribution to the portfolio to obtain portfolio returns.

Similarly, the return on market portfolio is represented by return on KSE-100 index $R_{m t}=L N\left[\frac{K S E(100)_{t}}{K S E(100)_{t-1}}\right]$, with $K S E(100)_{t}$ and $K S E(100)_{t-1}$ as the closing index values on day $\mathrm{t}$ and $\mathrm{t}-1$. The portfolio and market returns are then used to estimate excess portfolio returns $\left(\mathrm{R}_{\mathrm{p}}-\mathrm{R}_{\mathrm{f}}\right)$ and market risk premium $\left(R_{m}-R_{)}\right)$.

\section{III.IV.II. Size and Book-to-Market Portfolios}

The selected sample stocks were ranked by degree of market capitalization (price times number of shares) to denominate size from 2003 to 2007 , taking $31^{\text {st }}$ December of each year as the reference point. The median of the sample was used to split the stocks into two categories, namely big (B) and small (S). Table-2 represents the biggest, median, and smallest capitalization stocks in the sample.

Table-2: Size Sorted Portfolios (2003-2007)

\begin{tabular}{ccc}
\hline No & Size & Capitalization (Million of PKR) \\
\hline 1 & Maximum(B) & 180,308 \\
2 & Median & 4,682 \\
3 & Minimum (S) & 31 \\
\hline
\end{tabular}

The book-to-market $(\mathrm{BM})$ ratio is calculated by dividing the book value of equity by market value of equity on $31^{\text {st }}$ December for each year of the sample. Stocks are then ranked and categorized into three BM groups based on the break points of the bottom 30\% classified as low $(\mathrm{L})$, the middle $40 \%$ classified as medium (M), and the top 30\% classified as high (H). Six portfolios are formed on the intersection of two size and three book-to-market portfolios. These six portfolios are B/L, B/M, B/H, S/L, S/M and $\mathrm{S} / \mathrm{H}$. The $\mathrm{B} / \mathrm{L}$ portfolio contains stocks that are in the big group and have a low $\mathrm{BM}$ ratio; the $\mathrm{S} / \mathrm{H}$ portfolio contains stocks that are in the small group and have a high book-to-market ratio.

Fama and French (1996) and Lakonishok, Shliefer, and Vishny (1994) contend for equally weighted portfolios and suggest that the three-factor 
model performs even better in equally weighted portfolios than in valueweighted portfolios. Therefore, for this study, we build equally weighted portfolios to compute portfolio returns. Table 3 represents sector wideparticipation in these six portfolios.

Table-3: Sector-Wise Size and Book-to-Market Portfolios

\begin{tabular}{|c|c|c|c|c|c|c|c|c|}
\hline No & Sector & $\mathbf{S} / \mathbf{H}$ & $\mathbf{S} / \mathbf{M}$ & $\mathbf{S} / \mathbf{L}$ & $\mathbf{B} / \mathbf{H}$ & $\mathbf{B} / \mathbf{M}$ & $\mathbf{B} / \mathbf{L}$ & Total \\
\hline 1 & Auto Assembler & 1 & 0 & 1 & 0 & 0 & 2 & 4 \\
\hline 2 & Automobile Parts & 0 & 1 & 0 & 0 & 0 & 0 & 1 \\
\hline 3 & Banks & 1 & 0 & 0 & 1 & 6 & 2 & 10 \\
\hline 4 & Cable and Electrical Goods & 0 & 1 & 0 & 0 & 0 & 0 & 1 \\
\hline 5 & Cement & 1 & 0 & 0 & 2 & 2 & 0 & 5 \\
\hline 6 & Chemicals & 0 & 0 & 0 & 1 & 0 & 1 & 2 \\
\hline 7 & Engineering & 0 & 1 & 0 & 0 & 0 & 1 & 2 \\
\hline 8 & Fertilizers & 0 & 0 & 0 & 0 & 0 & 3 & 3 \\
\hline 9 & Food and Personal Care & 2 & 1 & 1 & 0 & 0 & 1 & 5 \\
\hline 10 & Glass and Ceramics & 2 & 2 & 0 & 0 & 0 & 0 & 4 \\
\hline 11 & Insurance & 0 & 3 & 0 & 0 & 0 & 2 & 5 \\
\hline 12 & Jute & 0 & 0 & 1 & 0 & 0 & 0 & 1 \\
\hline 13 & Leasing & 1 & 2 & 0 & 0 & 0 & 0 & 3 \\
\hline 14 & Leather & 0 & 1 & 1 & 0 & 0 & 0 & 2 \\
\hline 15 & Oil and Gas Exploration & 0 & 0 & 1 & 0 & 0 & 1 & 2 \\
\hline 16 & Oil and Gas Marketing & 0 & 0 & 0 & 0 & 2 & 2 & 4 \\
\hline 17 & Paper and Board & 0 & 1 & 0 & 0 & 0 & 1 & 2 \\
\hline 18 & Pharmaceutical & 0 & 2 & 0 & 0 & 0 & 1 & 3 \\
\hline 19 & Power & 3 & 0 & 0 & 1 & 1 & 0 & 5 \\
\hline 20 & Refinery & 0 & 0 & 0 & 0 & 0 & 2 & 2 \\
\hline 21 & Sugar & 2 & 1 & 0 & 0 & 0 & 0 & 3 \\
\hline 22 & Technology & 1 & 0 & 0 & 0 & 1 & 0 & 2 \\
\hline 23 & Textile & 2 & 2 & 0 & 0 & 1 & 0 & 5 \\
\hline 24 & Tobacco & 0 & 0 & 0 & 0 & 1 & 1 & 2 \\
\hline 25 & Transport & 0 & 0 & 0 & 1 & 1 & 0 & 2 \\
\hline \multirow[t]{2}{*}{26} & Vanaspati & 1 & 0 & 0 & 0 & 0 & 0 & 1 \\
\hline & Total & 17 & 18 & 5 & 6 & 15 & 20 & 81 \\
\hline
\end{tabular}




\section{III.IV.II. Market Premium SMB and HML Factors}

The market premium was estimated as the difference between returns on the KSE100 index and the 6-month T bill yield. As mentioned before, this factor is similar to CAPM, but incorporates two more risk factors, namely SMB and HML. The market risk premium was estimated as follows:

$$
R P_{t}=R_{m t}-R_{f}
$$

SMB capture the risk premium attached to returns related to firm size. It is the difference between the average returns on the three equally weighted small market capitalization portfolios and the three big market capitalization portfolios. Mathematically, we have:

$S M B=\frac{\lfloor S / L+S / M+S / H\rfloor}{3}-\frac{\lfloor B / L+B / M+B / H\rfloor}{3}$

HML accounts for the risk premium that is related to firm value. It is the difference between the returns on the portfolio of high book-tomarket ratio stocks and returns on the portfolio of low book-to-market ratio stocks, constructed to be neutral vis-à-vis size. It can be represented as follows:

$$
H M L=\frac{\lfloor S / H+B / H\rfloor}{2}-\frac{\lfloor S / L+B / L\rfloor}{2}
$$

Given that the data frequency is daily; all our estimates are on an intra-day basis.

\section{V. Hypotheses}

The regression model was applied to test the validity of the FF three-factor model. It was tested for the six size and book-to-market portfolios. The excess returns on each portfolio were regressed on three factors, namely market risk premium, size premium, and value premium. The model is expressed below:

$$
E R_{i t}=\alpha_{i}+R P_{t} \beta_{1 t}+(S M B) \beta_{2 t}+(H M L) \beta_{3 t}+e_{t}
$$


Since this is a multivariate regression model, the following hypotheses will be tested.

$$
\begin{aligned}
& H_{1}: \alpha_{P}=0 \\
& H_{2}: \beta_{i, 1}=0 \\
& H_{3}: \beta_{i, 2}=0 \\
& H_{4}: \beta_{i, 3}=0
\end{aligned}
$$

Where $\alpha_{P}$ represents the regression intercept and $\beta_{i, 1}, \beta_{i, 2}$ and $\beta_{i, 3}$ represent risk sensitivities of portfolio returns. The three-factor model will hold if the intercept is not significant (statistically 0 ) and the three slope coefficients are significant (statistically different from 0 ).

\section{Empirical Results and Analysis}

\section{IV.I. Descriptive Statistics}

Daily returns between January 2003 and December 2007 were computed for six sorted portfolios. Table-4 shows descriptive statistics for each portfolio:

Table-4: Descriptive Statistics of Daily Returns (2003-2007)

\begin{tabular}{lllllll}
\hline & $\mathbf{S} / \mathbf{M}$ & \multicolumn{1}{c}{$\mathbf{S} / \mathbf{L}$} & $\mathbf{S} / \mathbf{H}$ & $\mathbf{B} / \mathbf{M}$ & $\mathbf{B} / \mathbf{L}$ & $\mathbf{B} / \mathbf{H}$ \\
\hline Mean & $0.07 \%$ & $0.001 \%$ & $-0.01 \%$ & $-0.03 \%$ & $0.04 \%$ & $-0.06 \%$ \\
Median & $0.15 \%$ & $0.06 \%$ & $-0.07 \%$ & $-0.04 \%$ & $0.12 \%$ & $-0.10 \%$ \\
Maximum & $4.93 \%$ & $8.77 \%$ & $4.80 \%$ & $10.08 \%$ & $4.48 \%$ & $5.30 \%$ \\
Minimum & $-6.06 \%$ & $-10.80 \%$ & $-5.37 \%$ & $-7.02 \%$ & $-5.42 \%$ & $-5.57 \%$ \\
Std. Dev. & $1.20 \%$ & $2.04 \%$ & $1.24 \%$ & $1.55 \%$ & $1.21 \%$ & $1.43 \%$ \\
\hline
\end{tabular}

For the sample period, the $\mathrm{S} / \mathrm{M}$ portfolio offered the highest average daily return of $0.07 \%$, followed by $\mathrm{B} / \mathrm{L}(0.04 \%)$. The maximum per day return was yielded by big stocks with an average book-to-market ratio $(10.08 \%)$, and the minimum daily return for the observation period was yielded by small stocks with a low book-to-market ratio.

Daily standard deviations were on the higher side with $2.04 \%$ for S/L stocks as a maximum and $1.20 \%$ for the $\mathrm{S} / \mathrm{M}$ portfolio as a minimum. The higher standard deviations for all these portfolios demonstrate a high-risk profile for the sample stocks in specific and the Pakistani market in general. 
Table-5 documents similar characteristics for KSE 100 index returns.

Table-5: Descriptive Statistics of KSE 100 Daily Returns (2003-2007)

\begin{tabular}{cccccc}
\hline & Mean & Median & Maximum & Minimum & Std. Dev. \\
\hline KSE100 & $0.133 \%$ & $0.244 \%$ & $5.797 \%$ & $-6.042 \%$ & $1.515 \%$ \\
\hline
\end{tabular}

The mean average daily returns on the index portfolio are $0.133 \%$ with a maximum of $5.7 \%$ and a minimum of $-6.04 \%$ with a standard deviation of $1.51 \%$.

From 2003 to 2007, the average daily market risk premium was dominant as compared to size and value premiums. Interestingly, the magnitude of the average value premium was negative, due to negative mean returns on the $\mathrm{S} / \mathrm{H}$ and $\mathrm{B} / \mathrm{H}$ portfolios. Given negative mean returns for the HML factor, we can conclude that, on average, growth stocks outperform value stocks in terms of returns. However, the size premium was positive, with small stocks generating higher average returns and thus outperforming large caps. Table-6 summarizes the results for the three factors.

Table-6: Factor Statistics (2003-2007)

\begin{tabular}{lccc}
\hline & RP & SMB & HML \\
\hline Mean & $0.114 \%$ & $0.012 \%$ & $-0.065 \%$ \\
Median & $0.224 \%$ & $0.002 \%$ & $-0.122 \%$ \\
Maximum & $5.782 \%$ & $3.075 \%$ & $4.906 \%$ \\
Minimum & $-6.065 \%$ & $-3.919 \%$ & $-4.540 \%$ \\
Std. Dev. & $1.516 \%$ & $0.862 \%$ & $1.336 \%$ \\
\hline
\end{tabular}

Table-7 shows the correlation between the returns on portfolios. The maximum correlation is $32 \%$ between small stocks with a medium and low book-to-market ratio. The $\mathrm{B} / \mathrm{H}$ and $\mathrm{S} / \mathrm{M}$ portfolios also depict a similar level of correlation of returns.

Table-7: Correlations between Sorted Portfolio Returns

\begin{tabular}{cccccc}
\hline & $\mathbf{S} / \mathbf{M}$ & $\mathbf{S} / \mathbf{L}$ & $\mathbf{S} / \mathbf{H}$ & $\mathbf{B} / \mathbf{M}$ & $\mathbf{B} / \mathbf{L}$ \\
\hline $\mathrm{S} / \mathrm{L}$ & $32.22 \%$ & & & & \\
$\mathrm{~S} / \mathrm{H}$ & $8.42 \%$ & $13.19 \%$ & & & \\
$\mathrm{~B} / \mathrm{M}$ & $24.21 \%$ & $-37.24 \%$ & $17.70 \%$ & & \\
$\mathrm{~B} / \mathrm{L}$ & $-29.73 \%$ & $-12.24 \%$ & $-74.16 \%$ & $-9.23 \%$ & \\
$\mathrm{~B} / \mathrm{H}$ & $32.07 \%$ & $16.57 \%$ & $29.72 \%$ & $-4.54 \%$ & $-31.38 \%$ \\
\hline
\end{tabular}




\section{IV.II. Regression Results}

Our analysis was based on a multivariate regression. The dependent variables were the excess returns on six size and book-to-market portfolios; independent variables were the three risk premiums (RP), size premium (SMB), and value premium (HML). Table-8 provides the correlation matrix of independent variables, i.e., three risk premiums.

Table-8: Correlations between Independent Variables (2003 - 2007)

\begin{tabular}{ccc}
\hline & RP & HML \\
\hline HML & $0.76 \%$ & \\
SMB & $-5.58 \%$ & $-49.64 \%$ \\
\hline
\end{tabular}

The observed correlations between the three independent variables were negligible between market premium and value premium $(0.76 \%)$; and between market risk premium and size premium (-5.5\%). On the contrary, the coefficient was high for size risk premium and value risk premium, although in the opposite direction.

With a low correlation between market risk premium and size risk premium and value risk premium, it is clear that SMB provides a valid rationale for a size premium that is relatively free of market risk premium. Similarly, HML can be regarded as a measure of value premium that is not dependent on market risk premium.

Table-9 summarizes the results of the FF three-factor model. The test of the three factors assumes that the intercept should not be significantly different from 0 and that the slope coefficient should be significant. The study yields mixed results for the validity of the three-factor model. The estimated coefficients are encouraging for the existence of size and value premiums in the KSE, but they negate the presence of a market risk premium. In six size-to-value portfolios, the results were significant for four portfolios $(B / H, B / M, B / L, S / H)$ while for the $S / M$ and $S / L$ portfolios null hypotheses could not be rejected for the intercept. 
Table-9: Three-Factor Regression on Portfolios Sorted for Size and Book-to-Market Ratio ${ }^{4}$

\begin{tabular}{cccccccccc}
\hline & $\boldsymbol{\alpha}$ & $\boldsymbol{\beta}_{1}$ & $\boldsymbol{\beta}_{2}$ & $\boldsymbol{\beta}_{3}$ & $\mathbf{t}(\boldsymbol{\alpha})$ & $\mathbf{T}\left(\boldsymbol{\beta}_{1}\right)$ & $\mathbf{t}\left(\boldsymbol{\beta}_{2}\right)$ & $\mathbf{t}\left(\boldsymbol{\beta}_{3}\right)$ & $\mathbf{R}^{2}$ \\
\hline $\mathrm{B} / \mathrm{H}$ & -0.0001 & -0.012 & -0.013 & 0.692 & -0.475 & -0.593 & -0.312 & $25.821^{*}$ & 0.424 \\
$\mathrm{~B} / \mathrm{M}$ & 0.0001 & -0.003 & -1.057 & 0.352 & 0.205 & -0.158 & $-28.806^{*}$ & $14.869^{*}$ & 0.617 \\
$\mathrm{~B} / \mathrm{L}$ & -0.0001 & -0.015 & -1.070 & -0.957 & -0.792 & $-1.972^{*}$ & $-69.324^{*}$ & $-96.197^{*}$ & 0.890 \\
$\mathrm{~S} / \mathrm{H}$ & 0.0003 & 0.024 & 0.371 & 0.674 & 0.929 & 1.321 & $10.117^{*}$ & $28.573^{*}$ & 0.408 \\
$\mathrm{~S} / \mathrm{M}$ & 0.0009 & 0.046 & 0.137 & 0.444 & $2.928^{*}$ & $2.258^{*}$ & $3.352^{*}$ & $16.865^{*}$ & 0.210 \\
$\mathrm{~S} / \mathrm{L}$ & 0.0010 & -0.921 & 0.334 & 0.006 & $2.465^{*}$ & $-33.661^{*}$ & $6.019^{*}$ & 0.167 & 0.498 \\
\hline
\end{tabular}

The existence of a market risk premium along with size and value premiums was supported in the $B / L$ portfolio for which $R^{2}=0.89$. The value premium is significant for all portfolios and dominates the other two factors, although there is no size effect in the $\mathrm{B} / \mathrm{H}$ portfolio. The signs of coefficients for the four portfolios were consistent with the FF proposition. The SMB coefficient was positive for the small portfolio $(\mathrm{S} / \mathrm{H})$ and negative for big firms $\left(B / M^{5}\right.$ and $\left.B / L\right)$, confirming the size premium. Similarly, the HML factor was negative for low BM stocks $(B / L)$ and positive for high value stocks $(\mathrm{B} / \mathrm{H}$ and $\mathrm{S} / \mathrm{H})$, demonstrating the existence of a value premium.

The overall performance of the model was adequate with a high $\mathrm{R}^{2}$. Furthermore, to substantiate the presence of the size effect among big and small firms, $1 / 5$ of the sample firms around the median (17 in total) were eliminated. The remaining firms were sorted by size and book-to-market ratio, and the resulting factors were regressed on excess returns. The regression results for the reduced sample are reported in Table 10. These results confirm the existence of size and value premiums in the KSE for $\mathrm{B} / \mathrm{H}, \mathrm{B} / \mathrm{M}, \mathrm{B} / \mathrm{L}$ and $\mathrm{S} / \mathrm{H}$ portfolios. Moreover, insignificant coefficients for the $\mathrm{S} / \mathrm{L}$ portfolio in the full sample became significant in the reduced sample on controlling for the size effect.

Given these regression results, we can deduce that the bulk of results are in favor of the FF three-factor mode1 - at least in the case of KSE. In emerging markets like Pakistan, investors are more concerned about trading volumes and firm size. Since panics are common in such markets,

\footnotetext{
$4 *$ Significant at $5 \%$.

${ }^{5}$ The model was also tested by excluding the banking stocks for $\mathrm{B} / \mathrm{M}$ portfolio as it was likely that higher proportion of banks in portfolio could have contributed towards significant results. In the absence of banking stocks the results remained robust with significant market risk premium with $\alpha(0.001), \beta_{1}(0.05)^{*}, \beta_{2}(-0.88)^{*}, \beta_{3}(0.36)^{*}$ and $\left(\mathrm{R}^{2}\right.$ of 0.43$)$.
} 
investment decisions are driven by the presence of big liquid stocks and a premium is expected for small stocks.

Table-10: Three-Factor Regression on Portfolios with Reduced Sample Sorted for Size and Book-to-Market Ratio

\begin{tabular}{cccccccccc}
\hline & $\boldsymbol{\alpha}$ & $\boldsymbol{\beta}_{1}$ & $\boldsymbol{\beta}_{2}$ & $\boldsymbol{\beta}_{3}$ & $\mathbf{t}(\boldsymbol{\alpha})$ & $\mathbf{t}\left(\boldsymbol{\beta}_{1}\right)$ & $\mathbf{t}\left(\boldsymbol{\beta}_{2}\right)$ & $\mathbf{t}\left(\boldsymbol{\beta}_{3}\right)$ & $\mathbf{R}^{2}$ \\
\hline $\mathrm{B} / \mathrm{H}$ & 0.0007 & $0.0836^{*}$ & $-0.6744^{*}$ & $0.8308^{*}$ & 1.4633 & 2.6832 & -12.9119 & 23.5228 & 0.6062 \\
$\mathrm{~B} / \mathrm{M}$ & 0.0011 & $0.0911^{*}$ & $-0.5953^{*}$ & $0.0932^{*}$ & 0.9788 & 3.7042 & -14.4442 & 3.3431 & 0.2872 \\
$\mathrm{~B} / \mathrm{L}$ & 0.0011 & $0.0675^{*}$ & $-0.5233^{*}$ & $0.0188^{*}$ & 0.7790 & 3.1645 & -14.6280 & 3.5039 & 0.2468 \\
$\mathrm{~S} / \mathrm{H}$ & 0.0012 & $0.0892^{*}$ & $0.6090^{*}$ & $0.9329^{*}$ & 1.0802 & 3.5352 & 14.3986 & 32.6181 & 0.4829 \\
$\mathrm{~S} / \mathrm{M}$ & $0.0010^{*}$ & $0.0477^{*}$ & $0.1400^{*}$ & $0.2651^{*}$ & 3.3848 & 2.3989 & 4.1982 & 11.7544 & 0.1162 \\
$\mathrm{~S} / \mathrm{L}$ & 0.0007 & $0.1053^{*}$ & $0.4579^{*}$ & $-0.2552^{*}$ & 1.4520 & 3.1493 & 8.1720 & -6.7351 & 0.2071 \\
\hline
\end{tabular}

* Significant at $5 \%$

In this study, portfolios supporting the existence of size and value premiums consisted of stocks that were considered the best pick for local investors based on market activity and firm. An important consideration is that the sample period was, overall, a bull rally in Pakistan, and therefore results only confirm the presence of size and value premiums in a bullish market.

Nevertheless, an alternative explanation is possible for portfolios with significant intercepts and this could lead to further research. Daniel and Titman (1997) construct a characteristics model that expects non-zero intercepts when stocks have value premium loadings that are not balanced with their book-to-market ratio. Therefore, it is likely that the value loadings for $\mathrm{S} / \mathrm{M}$ and $\mathrm{S} / \mathrm{L}$ portfolios are not in proportion vis-à-vis their size and book-to-market ratios.

\section{Conclusion}

Asset pricing or, alternatively, expected rates of return are puzzles that financial economists have been trying to solve for almost half a century. The single- and multi-factor asset pricing models have had mixed results in different parts of the world. Some researchers advocate the single-factor beta as the most viable risk factor determining returns; others report that the beta term is no longer viable. This paper tries to explore the power of the FF three-factor model in an emerging market. 
The stocks were selected from the KSE were sorted into six portfolios at the intersection of size and book-to-market ratio. The sample period constituted daily stock returns between 2003 and 2007, and the KSE100 index was used as the benchmark for market returns with 6-month T-bill rate as the risk-free proxy. A multivariate framework was deployed to test for the validity of the three-factor model. The results showed that, except for two portfolios $(S / M$ and $S / L)$, the intercept terms were insignificant, implying that the FF three-factor model seemed to explain returns for the KSE. However, the market risk premium factor was relevant in explaining returns in only one of the six portfolios.

The empirical evidence suggests that the FF three-factor model is valid for the KSE. This observation has important implications for fund managers, investors, and corporate managers. Traditionally, fund managers and investors have used a single-factor model for portfolio management and asset valuation. The presence of two additional risk factors warrants their inclusion for investment analysis. The use of size and value premiums in addition to the market risk premium will result in a different risk return structure as compared with the single-factor model. The inclusion of additional risk premiums might require portfolio rebalancing by fund managers. Similarly, investors are likely to be willing to invest in small firms and value stocks to target higher returns. Moreover, with additional factors in place, the estimation of cost of equity might vary, and could ultimately change the estimates for project appraisals, financing choices, and composition of capital structure.

However, caution should be exercised since this research was conducted in a bullish market and it is not clear whether size and value premiums exist in a bearish market - this area is proposed for further research. It is proposed that the same data set be used to test the model without sorting the portfolios and to check its robustness for subtime periods (Jan 2003-June 2005 and June 2005-Dec 2007). It is further proposed that various data frequencies (weekly, monthly, etc.) should be used to test the efficacy of the model.

Asset-pricing models are valuable for deducing the economic rationale for investment decisions but they are burdened with problems when used to analyze human behavior. Financial economists have encountered problems whenever they have tried to model investor psychology and the results for a particular time period might not be representative of actual investment behavior in subsequent time periods. This is due to uncertain future economic environments that cause the deviation between theoretical models and practice - the same could be the case with this research. 


\section{References}

Akgiray, V., 1989, “Conditional Heteroscedasticity in Time Series of Stock Returns: Evidence and Forecast.” Journal of Business 62 : 55-80.

Aleati, A., Gottardo, P., Murgia, M., 2000, “The Pricing of Italian Equity Returns.” Economic Notes Vo1. 29, 2 : 153 - 177.

Bachelier, L., 1900, Théorie de la Spéculation. Annales de 1'Ecole Normale Supérieure de Paris.

Baese1, Jerome B, 1974, "On the Assessment of Risk: Some Further Consideration.” Journal of Finance 29, No. 5 : 1491-1494.

Barber, B. and J. Lyon, 1997, "Detecting Long-Horizon Abnormal Stock Returns: The Empirical Power and Specification Of Test Statistics.” Journal of Financial Economics Vo1. 43, 3 : 341-72.

Beltratti, Andrea. and di Tria, Massimo., 2002, "The Cross-Section of Risk Premia in the Italian Stock Market.” Economic Notes, Vo1. 31, 389416.

Berk, J., 1995, “A Critique of Size-Related Anomalies.” Review of Financial Studies, Vol. 8 : 275-286.

Black, Fischer, 1972, "Capital Market Equilibrium with Restricted Borrowing.” Journal of Business, Vo1. 45, 3 : 444-55.

Black, Fischer, 1993, "Beta and Returns", Journal of Portfolio Management, Vol. 20, $1: 8-18$.

Blume, E. Marchall 1971, “On the Assessment of Risk.” Journal of Finance Vol. 6, $1: 1-10$.

Breeden, Douglas T., 1979, “An Intertemporal Asset Pricing Model with Stochastic Consumption And Investment Opportunities.” Journal of Financial Economics, Vo1. 7 : 265-296.

Chan, Louis K., Narasimhan Jegadeesh and Josef Lakonishok, 1995, "Evaluating the Performance of Value versus Glamour Stocks: The Impact Of Selection Bias.” Journal of Financial Economics, Vo1. 38, $3: 269-296$. 
Chan, Louis K.C., Yasushi Hamao, and Josef Lakonishok, 1991, "Fundamentals and Stock Returns in Japan." Journal of Finance, Vol. $46,5: 1739-64$.

Claessens, S., S. Dasgupta, and J. Glen., 1995, "Return Behavior in Emerging Stock Markets.” World Bank Economic Review, Vol. 9, 1 : 131-151.

Connor Gregory, Sehgal Sanjay, 2001, "Tests of the Fama and French Mode1 in India.” Working Paper Financial Markets Group London School of Economics : 1-23.

Daniel and Titman, 1997, "Evidence on the Characteristics of Cross Sectional Variation in Stock Returns.” Journal of Finance, Vo1. 52, 1 : 1-33.

Davis, J., 1994, "The Cross-Section of Realised Stock Returns: The PreCOMPUSTAT Evidence.” Journal of Finance, Vol. 49 : 1579-1593.

Davis, James L., Eugene F. Fama and Kenneth R. French, 2000, "Characteristics, Covariances and Average Returns: 1929 to 1997." Journal of Finance, Vo1. 55 : 389-406.

Drew, E. Michael and Madhu Veeraraghavan., 2002, "A Closer Look at the Size and Value Premium in Emerging Markets: Evidence from the Kuala Lumpur Stock Exchange.” Asian Economic Journal, Vol. 17 : 337-51.

Drew, M.E and M. Veeraraghan., 2003, "Beta, Firm Size, Book-to-Market Equity and Stock Returns." Journal of the Asia Pacific Economy, Vol. $8,3: 354-379$.

Fama, Eugene F., and Kenneth French., 1992, "The Cross-Section of Expected Stock Returns.” Journal of Finance, Vo1. 47, 2 : 427-465.

Fama, Eugene F., and Kenneth French., 1993, "Common Risk Factors in the Returns on Stocks and Bonds.” Journal of Financial Economics, Vol. $33,1: 3-56$.

Fama, Eugene F., and Kenneth French, 1995, "Size and Book-to-Market Factors in Earnings and Returns." Journal of Finance, Vol. 50, 1 : 131-155. 
Fama, Eugene F., and Kenneth French., 1996, "The CAPM is Wanted, Dead or Alive." Journal of Finance, Vo1. 51, 5 : 1947-1958.

Fama, E. F. and K.R. French, 1998, "Value versus Growth: The International Evidence.” Journal of Finance, Vol. 53 : 1975-1979.

Ferson, W.E., S. Sarkissian and T. Simin, 1999, "The Alpha Factor Asset Pricing Mode1: A Parable.” Journal of Financial Markets, Vol. 2 : 4968.

Gaunt, C., 2004, "Size and Book-to-Market Effects and the Fama French Three Factor Asset Pricing Model: Evidence from the Australian Stock Market.” Accounting and Finance, Vo1. 44 : 27-44.

Griffin, J.M., 2002, "Are the Fama and French Factors Global or Country Specific?” Review of Financial Studies, Vo1. 15 : 783-803.

Grube1, Herbert G., 1968, "Internationally Diversified Portfolios." The American Economic Review, Vol. 58 : 1299-1314.

Halliwell, J., R. Heany R. and J. Sawicki, 1999, "Size and Book-to-Market Effects in Australian Share Markets: A Time Series Analysis." Accounting Research Journal, Vo1. 12 : 123-137.

Haugen, Robert A., 1995, The New Finance: The Case Against Efficient Markets. Prentice Hall, Englewood Cliffs, New Jersey.

Kothari, S.P., Jay Shanken, and Richard G. Sloan., 1995, "Another Look at the Cross-Section of Expected Stock Returns.” Journal of Finance, Vol. 50, $1:$ 157-184.

Lakonishok, Josef, Andrei, Shleifer and Robert W. Vishny, 1994, "Contrarian Investment, Extrapolation and Risk.” Journal of Finance, Vo1. 49 : 1541-1578.

Lintner, J., 1965, "The Valuation of Risk Assets and the Selection of Risky Investments in Stock Portfolios and Capital Budgets." Review of Economics and Statistics, Vol. $47: 13-37$.

Li, Wei and Hoyer-Ellefsen Richard, 2004, "Characteristics of Emerging Markets.” UVA-F-1453 Available at SSRN http://ssrn.com/abstract $=909890$ 
Malkiel B.G and Y. Xu., 1999, "The Structure of Stock Market Volatility." Working Paper, Princeton University Center for Economic Policy Studies.

Markowitz, H., 1952, "Portfolio Selection." Journal of Finance, Vo1. 7, 1 : 77-91.

Maroney, N. and A. Protopapadakis., 2002, “The Book-to-Market and Size Effects in a General Asset Pricing Mode1: Evidence from Seven National Markets.” European Finance Review, Vo1. 6 : 189-221.

Merton, Robert C., 1973, “An Intertemporal Capital Asset Pricing Mode1.” Econometrica, Vo1. 41 : 867-887.

Moerman, G. A., 2005, "How Domestic is the Fama and French ThreeFactor Model? An Application to the Euro Area." Working Paper SSRN : 1-32.

Mossin, J., 1966, "Equilibrium in a Capital Asset Market.” Econometrica, Vol. $34: 768-783$.

Roenfeldt, R., 1978, "Further Evidence on the Stationarity of Beta Coefficients.” Journal of Financial and Quantitative Analysis : 121145 .

Ross, Stephen A., 1976, "The Arbitrage Theory of Capital Asset Pricing." Journal of Economic Theory, Vo1. 13 : 341-360.

Sharpe, W., 1964, "Capital Asset Prices: A Theory of Market Equilibrium under Conditions of Risk.” Journal of Finance : 425-442.

Tobin, J., 1958, "Liquidity Preference as Behaviour Towards Risk.” Review of Economic Studies, Vo1. 67.

Williams, J. B., 1939, "The Theory of Investment Value." The Economic Journal, Vol. 49, 193 : 121 -122. 